\title{
WHO STRATEGIES AND ACTION TO PROTECT AND PROMOTE THE HEALTH OF WORKERS
}

\author{
IVAN DIMOV IVANOV, MD, PHD, SIENTIST \\ EVELYN KORTUM, MSC, TECHNICAL OFFICER
}

World Health Organization, Department for Public Health and Environment

\section{RESUMEN}

Las acciones de protección y promoción de la salud de los trabajadores se corresponde con uno de los mandato contemplados dentro de la Constitución de la Organización y contemplado en diferentes resoluciones de la Asamblea Mundial de la Salud. Teniendo en cuenta que la salud ocupacional se encuentra fuertemente relacionada con la salud pública y los programas de salud para el desarrollo, la OMS se encuentra organizando los determinantes de la salud en los trabajadores, incluyendo los riesgos para la enfermedad y los accidentes en el ámbito laboral, social e individual, así como el acceso a los servicios de salud. Además de priorizar las acciones enfocadas a considerar el lugar de trabajo como un espacio donde se debe proteger y promover la salud de los trabajadores y sus familiares.

Pese a los esfuerzos por implantar intervenciones efectivas orientadas hacia la prevención de las enfermedades ocupacionales y los accidentes laborales, todavía existen importantes diferencias entre los estatus de salud de los trabajadores entre y dentro de diferentes países, así, la 60 Asamblea Mundial de la Salud, celebrada en 2007, incluye un Plan Global de Acción sobre la Salud de los Trabajadores. Este Plan contempla programas orientados a desarrollar políticas, infraestructuras, tecnologías y trabajos conjuntos para alcanzar un nivel de protección básico de la salud en todos los trabajadores del mundo. La Asamblea Mundial de la Salud también instó a los 193 Estados Miembros de la OMS, a que desarrollen programas nacionales y las estrategias necesarias para facilitar la implantación del Plan Global de Acción y a trabajar en el sentido de su difusión para que logre alcanzar a todos los trabajadores, mediante intervenciones oportunas y servicios básicos orientados hacia la prevención de las enfermedades profesionales y de los accidentes laborales. Para ello cuenta con una extensa red compuesta por 65 centros colaboradores que dan soporte a las acciones de la OMS en materia de Salud Laboral.

Las prioridades en el marco de acciones de salud global para los siguientes diez años incluyen instrumentos relacionados con políticas en salud de los trabajadores, protección y promoción de la salud en los puestos de trabajo, servicios de salud laboral, desarrollo e implantación de prácticas basadas en la evidencia científica y otras políticas de salud concernientes a los trabajadores. De esta forma, las acciones de la OMS sobre la salud de los trabajadores contribuyen en gran medida a desarrollar la agenda de salud global orientada hacia la seguridad en salud, cambios climáticos y los Objetivos para el Desarrollo del Milenio.

\begin{abstract}
WHO's action on protecting and promoting the health of workers is mandated by the Constitution of the Organization and a number of resolutions of the World Health Assembly. Recognizing that occupational health is closely linked to public health and health systems development, WHO is addressing all determinants of workers' health, including risks for disease and injury in the occupational environment, social and individual factors, and access to health services. Furthermore, the workplace is being used as a setting for protecting and promoting the health of workers and their families.
\end{abstract}

Concerned that despite the existence of effective interventions to prevent occupational diseases and injuries there are still major gaps in the health status of workers between and within countries, the 60th World Health Assembly in 2007 endorsed the Global Plan of Action on Workers' Health. This Plan provides a political framework for development of policies, infrastructure, technologies and partnerships for achieving a basic level of health protection in all workplaces throughout the world. The Health Assembly also urged the 193 Member States of WHO to develop national plans and strategies for implementing the Global Plan of Action and to work towards full coverage of all workers with essential interventions and basic services for prevention of occupational diseases and injuries. A large network of 65 collaborating centres provides support to WHO's action on workers' health.

The priorities for global action in the coming ten years include policy instruments on workers' health, workplace health protection and promotion, occupational health services, evidence for action and practice, and workers' health in other policies. Thus, WHO action on workers' health contributes to the global health agenda with regards to health security, climate change and Millenium Development Goals. 


\section{WHO'S ROLE AND POLICY IN WORKERS' HEALTH}

The World Health Organization (WHO) is the directing and coordinating authority for health within the United Nations system. It is responsible for providing leadership on global health matters, shaping the health research agenda, setting norms and standards, articulating evidence-based policy options, providing technical support to countries and monitoring and assessing health trends.

The Constitution of WHO stipulates that "the enjoyment of the highest attainable standard of health is one of the fundamental rights of every human being without distinction of race, religion, political belief, economic or social condition." Aproximately 2.8 billion people, or about one-half of the world's population, are economically active. Their health is determined by a number of risks in the occupational environment, social factors, behaviours and access to health services. When carried out under favourable conditions, work provides income to support human needs and has a positive impact on health and well-being of individuals and on social and economic development.

However, the majority of the world's workers are still employed in unhealthy and unsafe working conditions resulting annually in about two million deaths from disease and injuries (Driscoll et al., 2005). Occupational risk factors account for substantial part of the burden of chronic diseases: $37 \%$ of back pain, $16 \%$ of hearing loss, $13 \%$ of chronic obstructive pulmonary disease, $11 \%$ of asthma, $8 \%$ of injuries, $9 \%$ of lung cancer and $2 \%$ of leukaemia (Concha-Barrientos et al., 2004). Furthermore, about $8 \%$ of burden of disease from depression is attributed to occupational risks (Prüss-Üstün and Corvalán, 2006). Despite that, still only a tiny minority of workers have access to occupational health services to prevent disease and injury at work.

The workplace provides ample opportunities to implement public health interventions, such as treatment of tuberculosis, immunizations against certain infectious diseases, tobacco control, as well as promotion of healthy diet, physical activity, well-being and mental health. The workplace also allows to disseminate among workers, their families, and neighbouring communities certain important public health messages to prevent and control HIV/AIDS, malaria and other major health threats. In some countries, primary healthcare services are being provided through the workplace.
The main functions of WHO mandated in article 2 of its Constitution include promoting the improvement of working conditions and other aspects of environmental hygiene. In the 1970s, the World Health Assembly, the supreme governing body of WHO, stressed that occupational health is part of public health, that occupational health services need to be further developed (Resolutions WHA 25.63 and 28.73). Then, the Health Assembly urged the Member States to study health problems of workers, to organize capacity building, monitoring and special care of vulnerable groups and to improve the reporting of occupational diseases (Resolution WHA 29.57). The 33rd World Health Assembly held in 1980 established a global programme of action on workers' health to support developing countries and to facilitate the transfer of experience and knowledge from the developed to the developing world, as well as to study different examples of the role of various ministries in occupational health and workplace inspection (Resolution WHA 33.31). In 1996, the 49th World Health Assembly endorsed the Global Strategy on Occupational Health for All as a comprehensive political framework for WHO's action on occupational health (Resolution WHA 49.12). This Strategy inspired a number of Member States to devise national policies and strategies for occupational health and safety and to take measures to improve the protection and promotion of health at work.

The processes of social transformation and globalization over the last decades have brought about changes in the world of work which provide new opportunities and challenges to protecting and promoting health at work in addition to the traditional occupational health. The World Summit on Sustainable Development, Johannesburg 2002, recommended strengthening and promoting WHO's programme to "reduce occupational deaths, injuries and illnesses, and link occupational health with public health promotion as a means of promoting public health and education." (WSSD Plan of Implementation, 2002) Furthermore, a number of ministerial conferences have called upon WHO to scale up its action on workers' health.

\section{WHO'S GLOBAL PLAN OF ACTION ON WORKERS' HEALTH 2008-2017}

The 60th World Health Assembly in 2007 expressed concern that despite the existence of interventions for primary prevention of occupational hazards and for developing healthy workplaces there are still major gaps between and within countries in the exposure of workers and local communities to occu- 
pational hazards and in their access to occupational health services. Stressing that the health of workers is an essential prerequisite for productivity and economic development, the Health Assembly endorsed a Global Plan of Action on Workers' Health for the period 2008-2017 (Resolution WHA60.26). The 193 Member States of WHO were urged to devise national policies and plans for its implementation in consultation with workers, employers and their organizations and to work towards full coverage of all workers, including those in the informal economy, small- and medium-sized enterprises, as well as agricultural and migrant workers with essential interventions and basic occupational health services for primary prevention of occupational and workrelated diseases and injuries. Particular measures were required to establish and strengthen core institutional capacities and ensure adequate human resources for addressing the specific health needs of the working population. The Health Assembly emphasized the importance of ensuring collaboration between all national health programmes, relevant to workers' health. These include occupational health, communicable and chronic diseases, health promotion, mental health, environmental health and health systems development. In addition, the Member States were invited to address the health and environmental problems of local communities arising from industrial activities, to incorporate workers' health into the policies for sustainable development, poverty reduction, employment, trade, environmental protection and education; and to develop strategies to ensure re-integration of sick and injured workers into the mainstream of society.

The WHO Global Plan of Action on Workers' Health provides a new policy framework for concerted action to protect, promote and improve the health of all workers. The Plan addresses all aspects of workers' health, including primary prevention of occupational hazards, protection and promotion of health at work, employment conditions, and improving the response of health systems to workers' health. In such a way it links occupational health to public health The priorities for WHO's global action on workers' health are: (1) devising and implementing policy instruments on workers' health; (2) protecting and promoting health at the workplace; (3) improving the performance of and access to occupational health services; (4) providing and communicating evidence for action and practice; and (5) incorporating workers' health into other policies.

The Plan of Action is intended to guide the Member States and WHO in their activities on workers' health over the period 2008-2017. It is expected that it will stimulate the development of policies, infrastructure, technologies and partnerships for improving the health of all workers. In such a way it will contribute towards achieving a basic level of health protection in all workplaces throughout the world. WHO, through its Headquarters, six Regional and 144 Country offices, will work with the Member Strates to implement the Global Plan of Action. In particular, WHO will promote and engage in partnerships with other UN agencies and with major international stakeholders. It will set international standards, articulate policy options for national agendas, as well as monitore and address trends in workers' health. The progress made will be reviewed by the World Health Assembly in 2013 and 2018 based on a basic set of indicators of achievement.

Furthermore, WHO maintains a large network of 65 collaborating centers in occupational health that contribute directly to the implementation of global and regional initiatives and enhancing their scientific validity. WHO collaborating centers are institutions of high scientific and technical standing having attained international recognition. The Network of WHO Collaborating Centres in Occupational Health implements a Workplan 2006-2010 including over 150 international and collaborative projects in support of WHO's policy and strategy in workers' health. The work of the collaborating centres is directed towards analysis of the global situation and trends, evidence for national policies, practical approaches to reducing occupational risks, education, training, and technical materials, development and expansion of occupational health services, as well as communication and networking.

\section{WORKERS' HEALTH AND WHO'S GLOBAL PUBLIC HEALTH AGENDA}

Healthy and safe workplaces are considered essential prerequisite for preventing chemical and radiological accidents. The spread of certain major public health threats, for example SARS and avian influenza can be prevented through actions at the workplace. Hence, action on protecting workers' health and safety can contribute to global public health security.

Climate change has a number of implications for the workplace. For example, extreme weather events, such as heat waves, require adjusting work time schedules, providing adequate ventilation and drinking water supply to prevent ill health resulting from excessive heat. The introduction of clean technologies and systems for management of health at work promotes the development of sustainable, 
healthy and safe workplaces that are also energy efficient and with less impact for the environment.

The achievement of the Millennium Development Goals requires breaking the vicious cycle between poverty, hazardous working conditions and ill health, elimination of hazardous child labour, promotion of women's health and protection of reproductive health at work, and combating HIV/AIDS, malaria and other major diseases at the workplace.

WHO's action on workers' health will contribute to address these global challenges by establishing and sustaining partnerships with other UN agencies

\section{BIBLIOGRAPHY}

Concha-Barrientos $\mathrm{M}$ et al. Selected occupational risk factors. In: Ezzati $\mathrm{M}$ et al., eds. Comparative quantification of health risks: global and regional burden of diseases attributable to selected major risk factors. Geneva: World Health Organization, 2004:1651-801. and major stakeholders, such as the International Labour Organization, the United Nations Development Programme, the International Social Security Association, as well as with the organizations of workers and employers, private sector, and civil society.

The authors are staff members of the World Health Organization. The authors alone are responsible for the views expressed in this publication and they do not necessarily represent the decisions, policy or views of the World Health Organization.
Driscoll $\mathrm{T}$ et al. Review of estimates of the global burden of injury and illness due to occupational exposures. American journal of industrial medicine 2005;48:491-502.

Prüss-Üstün A, Corvalán C. Preventing Disease through Healthy Environments. Geneva: World Health Organization, 2006. 